\title{
Teaching modern foreign languages in primary classrooms in Uzbekistan: an overview
}

\author{
Tajibev Gairatjon Shovdorovich \\ (Ph.D.) senior teacher at the department of foreign language teaching methodology at \\ Namangan State University, Uzbekistan \\ Nematjonov Sharifjon Rustamjonovich \\ Teacher at the department of foreign language teaching methodology at Namangan \\ State University, Uzbekistan \\ Valiev Kobiljon Obidjonovich \\ Assistant teacher at the department of foreign language teaching methodology at \\ Namangan State University, Uzbekistan \\ Email:_tajibev_g@umail.uz
}

\begin{abstract}
This article aims to present foreign language learning in primary school as a part of educational system of Uzbekistan. Language policy concerning educational system is described briefly, but the main focus is on basic education in Uzbekistan and especially on primary foreign language education, its curriculum and aims. After presenting some sociolinguistic background information and a short outline of Uzbekistan's school system in general, we will focus attention on different aspects of early language learning at primary school level. We will conclude our outline with some personal comments on current challenges and problem areas in the field of early foreign language learning in Uzbekistan.
\end{abstract}

Keywords: primary education, foreign language learning, language policy, pedagogy, methodology, core curriculum, syllabus, goal, approach, communication

\section{INTRODUCTION}

Teaching of modern foreign languages (English, German, and French) at the primary level is a worldwide phenomenon. In Uzbekistan, the teaching of foreign languages and its introduction have received great attention as the government officially approved an earlier proposal to extend the teaching of modern foreign languages to all primary schools as a compulsory subject from grade 1.

As we approach the millennium, the learning of modern foreign languages plays a central role to provide the possibility of practical communication; it is also a source of valuable intellectual stimulation and enjoyment; it cultivates broader perspectives and insights into other cultures and enables people to gain insights into their own culture and language through contrast. But an early start to foreign language learning has particular advantages and to successfully teach children a foreign language in Uzbekistan context requires specific skills and intuitions that differ from those appropriate for European countries.

\section{METHODOLOGY}

Since 1991, when Uzbekistan proclaimed its independence dramatic changes took place in all sectors and respectively in education as well. According to Constitution adopted in 1992, the Republic of Uzbekistan provides and supports languages, customs and traditions of all nationalities living in the country to be respected and developed (chapter 4). Furthermore, chapter 41 guarantees all its citizens the right to receive primary and secondary special education free of charge. In 1995 Uzbekistan took an active part in the discussions of the Declaration of Principles of Tolerance of UNESCO and successfully implemented it into national laws (www.un.org). According to the law about "State Language" all 
citizens of Uzbekistan have the right to choose a language for primary and secondary special education. For instance, primary and secondary education is offered in 7 languages (www.lex.uz).

Table 1. A number of schools and pupils' education is offered in languages (www.uzedu.uz).

\begin{tabular}{|c|c|c|c|c|c|c|c|}
\hline Languages & Uzbek & Russian & Kazak & Karakalpak & Tajik & Kirgiz & Turkmen \\
\hline $\begin{array}{c}\text { Number of } \\
\text { schools }\end{array}$ & 8825 & 836 & 380 & 363 & 247 & 57 & 56 \\
\hline $\begin{array}{c}\text { Number of } \\
\text { pupils }\end{array}$ & 4116420 & 478008 & 48008 & 94791 & 55270 & 6731 & 8835 \\
\hline
\end{tabular}

At the age of 6 (5) children have a month's short term course at elementary schools to get accustomed and to adopt school life. General education has two stages: primary education comprising grades $1-4$ and optional education with grades of 5-9. When pupils finish their general education they choose either academic lyceums or vocational training collages for further 3 years of compulsory education. Basic education is organized in public schools, but there are also some private primary schools. Another feature of the country's school system is that there are no school fees. All school aged children get president's gift in the form of school bags, books and other learning materials. Dropping out of school is rare and almost all children complete their basic and secondary special education.

\section{FOREIGN LANGUAGE LEARNING IN PRIMARY EDUCATION}

Uzbekistan has a long enough tradition of teaching foreign languages to young children. The evidence to support the idea dates back from the "Great Silk Road" period when the present day territory of Uzbekistan used to be a center for world trade, science and culture. Uzbek merchants were fluent speakers in distinctively different languages such as Persian, Arabic or Chinese because bilingualism or monolingualism always had practical concern to study, to make business and for intercultural communication. In the 19th century Central Asia (Kazakhstan, Turkmenistan, Tajikistan, Uzbekistan, Kirgizstan, and Afghanistan) used to be the territory of three kingdoms (the Khiva Kingdom, the Kokand Kingdom and the Bukhara Emirate) whose administrative principle cities were all located within the territory of today's Uzbekistan. Even though everyday communication was carried in different Turkish dialects, Arabic and Persian were still in use for trade, religion and administration. During the Second World War millions of war victims from Russia, Belorussia, The Ukraine, and North Korea were evacuated to the country. This caused a further variation of the country's ethnic makeup and Russian became a language for communication.

So, we can agree with the notion of Kelly (1969) and Howatt (1984) demonstrating that many current issues in language teaching are not particularly new. Today's controversies reflect contemporary responses to questions that have been asked often throughout the history of language teaching (cited in Richards \& Rodgers, 2009). But today's questions are more concerned with the starting age of language learners and the language to be learned. Whereas today English (respectively German and French) is the most widely learned foreign languages in Uzbekistan; until independence Persian, Arabic and Russian enjoyed popularity, for they were the dominant languages of education, commerce, religion and government. Traditionally foreign language teaching considered teenagers and adults. Reformations evolved the problem of creating optimal conditions for foreign language learning in primary classrooms.

Today with 32 million citizens Uzbekistan is a multinational, multicultural and most densely populated country in Central Asia. In multicultural and multinational Uzbekistan Russian has kept its status as a second language for communication and until 2013 early characterized the learning of Russian and it was the only compulsory language in primary classrooms. Learning and teaching Russian at an early age was developed on the base of bilingual education principles which now being referred as Content and Language Integrated Learning (CLIL) perspective. Because, there were many bilingual schools where education was oriented to teach the other language of the country (Admiraal et al. 2006); language minority children (Korean, Armenian, Tajik, Ukrainian, Jewish and est.) were taught in the language of the majority group (Dalton-Puffer, 2007); Russian was used as the medium of instruction to teach content subjects by native speakers. Besides, children had plenty of time for language exposure and comprehensible input in different settings. At home a child watched cartoons in Russian, outside he saw road signs and mottoes in two languages, met people talking in Russian. On the other hand a child had enough reason to use Russian to communicate with caregivers, teachers, shop assistants, drivers, barbers, librarians or photographers who were native or native-like speakers. So, we can assume that Russian in Uzbekistan context was not learned but naturally acquired. Because, firstly children had plenty of time and exposure for discovery learning (J. Piaget:1926) and it spread over several years, secondly they had a need to use Russian in order to have something done, e g to shop, to make friends, thirdly they received 
plenty of meaningful language input through experience of Russian not as a subject to be learned, but as a means of communication by scaffolding (L.Vigotskiy:1934; J.Bruner:), where the focus is on the meaning not the form of the language.

In 2012 the First President of the Republic of Uzbekistan's resolution "About the measures on further development of foreign language teaching and learning system" made foreign language a compulsory subject of primary education (www.lex.uz). According to the Core Curriculum renewed in 2014 all children are to learn at one foreign language (especially English) from the first year of schooling, at the age of 7 (6). This decision demonstrated that the Uzbek state has finally acknowledged that learning and teaching modern foreign languages is a priority area. Since then primary foreign language education has been enjoying special attention and has been the focus of research, innovation and practical considerations. With 9692 primary schools having an enrolment of 4116420 students in 2016, there is now an urgent demand for foreign language teachers with specific qualifications to facilitate learning in primary classrooms effectively (www.uzedu.uz).

\section{TABLE 2. PUPILS LEARNING FOREIGN LANGUAGES IN PRIMARY CLASSROOM}
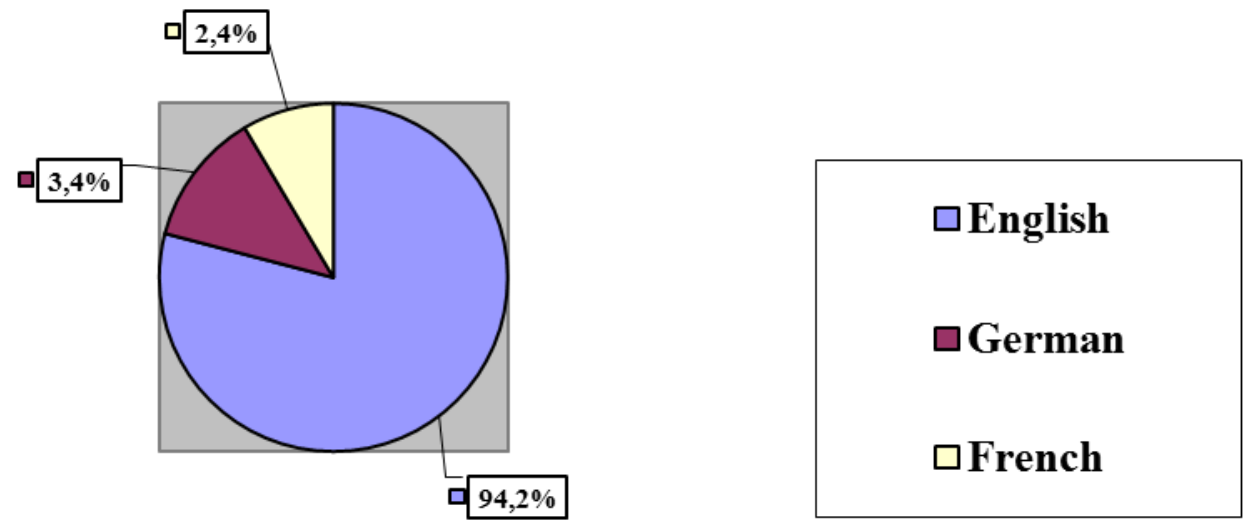

Learning and teaching foreign languages is distinctively different from traditional Russian language acquisition in Uzbekistan situation because of the following factors:

- $\quad$ a limited amount of time spent on foreign languages (on average, pupils in grade 1 have two 45-minute foreign language lessons per week (66 hours a year), pupils in grades 2-4 have two 45minute lessons per week (68 hours a year), pupils in grades 5-9 have three 45-minute lessons per week (102 hours a year),

- $\quad$ no need or reason for using foreign languages as the country is located far from Europe and one can hardly see a native speaker,

- a formal learning environment with the focus mainly on correctness,

- $\quad$ native teachers previously taught in secondary classrooms,

- a limited and controlled language input.

Taking above mentioned factors the government of Uzbekistan initiated a nation-wide curriculum innovation in 2014 to promote learning English, German and French as foreign languages in primary schools.

\section{Goals and approaches in foreign language teaching}

Foreign language education in primary schools in Uzbekistan is based on the National State Standard and Core Curriculum for Foreign Languages of the Republic of Uzbekistan approved by Cabinet Ministers and on Core Syllabus of Foreign Languages for Basic Education (grades 1-9) prepared by the Republican Center for Education under the Ministry of Public Education in 2013. The Core Curriculum and Syllabus are normative guidelines for teaching and educational work and it provides the goals, practical, general educational and developmental objectives and main content of the foreign language subjects. The primary foreign language studies form the ground for future lifelong language learning formal and informal.

The philosophy underlying the Uzbek educational system is to equip younger generation with the competencies required for their future lives and jobs and to encourage life-long learning. The concept of language teaching is based on the communicative-cumulative method and child-centered approach. According to the recent reformations, the overall goal of foreign language teaching and learning is to prepare a culturally aware and cognitive language user. Practical objective of foreign language teaching is 
to facilitate mastering the language proficiency at A1 level. Level A1 is divided further into more specified levels A1/1 for grade 1, A1/2 for grade2, A1/3 for grades 3-4.Primary MFL (modern foreign language) is not only an investment for the future but it also reflects our values as modern citizens and our conception of what it means to be educated. The goals of primary MFL are to prepare specialists capable in the target languages, and on the base of this to provide them with the opportunities to enjoy the boons of modern world civilization and to access the intellectual wealth (Core Syllabus for general educational schools (for 1-9 grades)). In the Core Curriculum the aims and evaluation criteria concerning language teaching are based on the Common European Framework of Reference for Languages (CEFR). These pan-European recommendations have been modified to suit the context in Uzbekistan. In the core curriculum the aim of enabling learners to communicate and express themselves in a foreign language is expressed in terms of four areas of proficiency known as the four major skills: listening, speaking, reading, and writing.

According to the Core Curriculum for grade 1 listening comprehension and speaking skills are emphasized whereas writing is not introduced. A further aim is to encourage the pupils to use the language in a functional and creative way (plays, games, nursery rhymes, songs etc.). Emphasis is not only placed on language use, but also on creating a basis for language study skills and taking an interest in foreign language learning. The core contents are related to the pupils' interests and everyday life such as home and school. In addition, pupils are introduced to the target language's culture. In grades $3-4$, the objectives and core contents for foreign language education are more specified than in grades $1-2$. The objectives include language proficiency, cultural skills and learning strategies. The general objective of foreign language instruction is that pupils learn to communicate in the target language in simple speaking situations. Writing is increased gradually and emphasis is put on everyday life needs such as short messages. A further objective is that the pupils - besides getting to know the culture of the target language - realize that there are differences in cultures and languages and despite these they are equal in value. Another objective of the instruction is that pupils develop good language study habits such as recognizing their own strengths and weaknesses as a language learner. The authors (Jalolov J.J. et al) of the Core Syllabus advocate communicative-cumulative integrated approach in language teaching focused on developing individuals' specific communicative competence to function more successfully in order to survive in different sectors of the rapidly changing society (Core curriculum for general education 2014).Despite world-wide criticism (Enever and Moon:2009)pointing out that CLT is a method that has its origins in EFL teaching for adults in western countries where groups are small and classrooms wellequipped. It may not, therefore, be appropriate for teaching children in over-crowded classrooms with few resources and very different educational traditions (G. Hu: 2002). But state policy in Uzbekistan remains unchanged and the government is supporting and compensating this approach by equipping classrooms with all necessary technical aids and complex of methodological materials(pupil's' book, teacher's book, workbook, exercises book, reading book) approved by the government("Kids' English 1,2,3,4”, "Deutsch macht spab 1,2,3,4"and "Hirondelle 1,2,3,4") and limiting the amount of learners to 15 . The government also financing English-only summer camps to provide the opportunity to be exposed to English outside of school all the learners regardless of socioeconomic background. Care takers in these camps are foreign language faculty students who want to earn during summer holiday.

Although government policies and curricula typically advocate teaching communicatively, this approach is often incompatible with the demands of national examinations which continue to be grammar-based. Many teachers still use traditional formal grammar-focused approaches because they a) have no appropriate competency on the methodology of foreign language teaching to young learners and high proficiency, b) compensate their low level of communicative competence and try to keep the class under control, c) are under pressure to complete the syllabus and prepare for grammar based examinations.

\section{Teacher Qualification Demanded}

In many societies, teaching children is seen as an extension of mothering rather than as an intellectual enterprise. Teachers at primary level are then often given less training, lower status, and lower pay, than their colleagues in the same educational system who teach teenagers or adults (L.Cameron; 2005. P.XII). In Uzbekistan primary classroom teachers are privileged. Because teaching children is considered a difficult and time consuming job and it takes a very special person who understands how children make sense of the world and how they learn, plus a knowledge of the language, of language teaching, and of language learning. Persons specializing in the teaching of two foreign languages have been the norm in secondary education for decades. At a time when Uzbekistan was lowering the age of initial foreign language learning, it faced an acute shortage of adequately trained teachers for primary education. The country thus started training specialists for this level, in addition to their language specialization, were experts in the teaching methodology for the corresponding age-group.

Uzbekistan is still a novice in preparation primary foreign language teachers and there is no unified path on how to become an appropriately trained primary MFL teacher. According to the "Law 
about Education", all primary school subjects are taught by class teachers but foreign languages are taught by language teachers with bachelors degree of philology and language teaching (5120100) or foreign languages and literature (5111400). In order to provide foreign language learning on high standards, government is providing classrooms with multimedia-based modern technologies (interactive whiteboards, CD-ROMS). This may be viewed as a way of compensating for underqualified teachers or those with low proficiency.

\section{Conclusions}

Considering that young learners themselves wish to have teachers who are confident in their use of English (Butler, 2007), policy has focused on local teachers and encouraging them to become fluent speakers. State Test Center under the Cabinet Ministers holds proficiency tests for foreign language teachers. Most successful applicants will be certified for extra 30 percent payment to their monthly salary. That means those obtained Certificate endorsed by State Test Center or other internationally appreciated certificates as TOEFL or IELTS are more likely to be paid more. This is the way the government encourages teachers to be more qualified specialists (of child psychology, pedagogy and foreign language teaching methodology) of primary foreign language teaching. The government also offers 120 hours of mandatory training courses in regional teacher training and retraining institutions. As above mentioned4116420 pupils are enrolled in primary classrooms and to teach this amount of learners 27532 teachers (21758 English, 3414 German, 2345 French) have been employed in this sector. Every Friday these teachers have local meetings for seminars, webinars and workshops held by Seeded teachers (expert teacher trainers with foreign experience) in certain responsible schools and branches of UzTEA (Uzbekistan Teachers of English Association). Annually the Ministry of Public Education and the Ministry of Higher and Secondary Specialized Education with teacher training practical-scientific center under Uzbekistan World Languages University, British Council, Goethe Institute and French Embassy in Tashkent organize "Best Teacher of the Year" contest to select the most appropriate candidates for scholarships to study abroad.

Taking into consideration above, we can make a conclusion that primary foreign language education in Uzbekistan is being developed on the following factors:

society,

- $\quad$ positive and supporting attitude towards learning foreign languages at an early age in the

- designing age appropriately single core-curriculum, syllabus, methodological and pedagogical teaching materials focused and based on internationally approved framework criteria,

- $\quad$ specially equipped classrooms with display of wide range of choice of technical and nontechnical materials to create the optimal condition for learning to take place,

- $\quad$ minimizing the class size to no more than 15 learners,

- $\quad$ providing all teachers and learners with necessary materials free of charge,

- holding in-service teacher training courses, Friday workshops, seminars and on-line webinars for primary classroom practitioners,

- $\quad$ offering 30 percent extra payment to the monthly salary of the teachers holding certificates by the State Test Center,

- organizing "The year's best teacher of foreign languages" contests that guarantee a scholarship for teacher training courses in Europe.

Since teaching modern foreign languages to young learners in its puberty in Uzbekistan there are some problematic issues of the day for quality improvement in this area.These are a) to establish special local university faculties oriented primary foreign language teachers with special competencies on pedagogy, psychology and foreign language teaching methodology, b)to organize retraining courses for candidates holding bachelor diploma of pedagogy or philology, c) to provide distant or on-line courses for the teachers from rural areas.

\section{REFERENCES}

1. Admiraal, W., Westhoff, G., de Bot, K., 2006. Evaluation of Bilingual Secondary Education in The Netherlands: Students' language proficiency in English. Educational Research and Evaluation 12, 75 - 93.

2. Cameron, L., 2001. Teaching Languages to Young Learners. Cambridge: Cambridge University Press.

3. Dalton-Puffer, C., 2007. Outcomes and processes in Content and Language Integrated Learning (CLIL): current research from Europe, in: Future Perspectives for English Language Teaching. Carl Winter, Heidelberg.

4. Enever, J., and Moon, J., 2009. New global contexts for teaching Primary ELT: change and challenge. In J. Enever, J. Moon and U. Raman (Eds.), Young Learner English Language 
Policy and Implementation: International Perspectives (pp. 5-21). Reading: Garnet Education.

5. Hu, G. (2002). Potential cultural resistance to pedagogical imports: the case of communicative language teaching in China. Language, Culture and Curriculum, 15(2), 93-105.

6. State Standard for Foreign Languages of Continuous Education of the Republic of Uzbekistan. Tashkent: Public Education - scientific methodological journal. 2013.

7. Ministry of Public Education, Curriculum on English (German, French) for General comprehensive schools. Tashkent: Public Education - scientific methodological journal. 2013.

8. Piaget.J. Le Langage et la penséechez l'enfant (1923); The Language and Thought of the Child (1926); Речь и мышление ребенка - М.: Римис, 2008.

9. Выготский. Л.С. Мышление и речь (1934). - М.: Лабиринт, -1999. 